\title{
ANIMALS AS CRIME VICTIMS
}

\author{
Alexander M. Pleshakov ${ }^{1}$ \\ Gennadiy S. Shkabin ${ }^{2}$
}

\begin{abstract}
Animals often become a vertebrates. The authors conclude that subject of criminal attacks. However, attacks on animals harm the moral their legal status is not well defined. The principles of society. They propose to article is devoted to the analysis of the contradictions between the legal and consider only mammals and birds as a subject of cruelty to animals.
\end{abstract} biological characteristics of animals that have been subjected to criminal action. Today, in civil and criminal law they are considered as things, that is, inanimate objects. At the same time, numerous studies of the elementary behavior of representatives of the fauna show that, they can feel, experience emotions and possess rational abilities. In this regard, it becomes necessary to study further the legal status of animals, especially those who can carry out reasonable activities. The article provides various opinions of scientists on this issue. Attention is drawn to the position of authors who regard animals as a thing, animate objects. The authors' position is expressed regarding proposals on the criminal legal protection of only

Keywords: Animals Criminal law A crime Violence Mammals Animate objects

\section{Introduction}

The existence of a man is not always associated with creation in the natural environment. Unfortunately, people sometimes commit crimes, including against living creatures like animals (Beirne, 2014). In general, we agree with B. Fischer that scientific and technological progress is unlikely to improve the situation of animals in the modern world (Fischer, 2019). Modern criminological studies demonstrate the connection between violence against fauna and the commission of crimes

Department of Criminal Law, Moscow University of the Ministry of Internal Affairs of Russia named ${ }^{1}$ after V.Ya. Kikotya, Moscow, Russia

Research Center (SIC) - 2, Research institute of the Federal Penitentiary Service of Russia, Moscow, ${ }^{2}$ Russia 
against people (Coorey \& Coorey-

Ewings, 2018; Flynn, 2011).

However, the perception of them as victims of a crime is highly controversial (Brewster \& Reyes, 2012). Thus, the current criminal law most definitely considers the animal-victim as the subject of a criminal attack. In other words, it is a thing of the material world. However, no one doubts that we are talking about an animate being in most cases. The purpose of this article is consideration of this contradiction.

\section{Materials and Methods}

In the research process, we used various empirical methods: documentary-analytical (content analysis) and specific sociological. The largest amount of information was obtained using content analysis. We have identified and studied 483 cases of the use of animals, described in the mass media, in the violent crimes commission. This method was aimed at achieving the following two goals: to form a general idea of the conflict relations between humans and animals and to evaluate the situations in which such events occur; to investigate the extreme degree of such confrontation and establish the frequency of ethnozoological crimes.

\section{Results}

According to the etymology of the word, any object is any material thing (Ozhegov \& Shvedova, 1995). In turn, a thing is that which consists of the essence of the inorganic world, of the type of matter perceived, visible and tangible. Therefore, the thing is a material substratum that can be physically exposed.

In order to determine the "objectivity" of animals, it is necessary to turn to civil law regulations. In accordance with Art. 128 of the Civil Code of the Russian Federation (hereinafter - the RF CC) things, that are property, consider as the objects of civil rights. This conclusion follows from the text of the law, since things include the kind of object, such as other property. Thus, animals are things and property, because according to Art. 137 of the RF $\mathrm{CC}$, the general rules on property apply to them. The Civil Code of the Russian Federation has an exception on this subject: "since the law or other legal acts do not establish otherwise."

This last part of the article ("otherwise") raises serious doubts. It is difficult to imagine anything else in the relationship between a man and an 
animal. However, in accordance with the grammatical interpretation of the law, apparently, some hypothetical situations are permissible when animals are not legally recognized as property.

In our opinion, it is unlikely that we will face this kind of "other" legislative decision in future. However, in general household notions, this abstract position is completely allowed and even actively discussed. We believe that causing harm to animals encroaches on the moral principles of society. But at the same time, we cannot always see the moral experiences of other living beings. We believe that the criminal law should protect only mammals and birds. This conclusion is based on generally accepted notions of people about the "moral" closeness with such animals.

\section{Discussion}

For a long time, scientists have expressed the opinion in legal literature that animals cannot be considered as things. It is argued that animals cannot be called things because they are living things (Kitaeva, 2010). From the concepts of things, "our little brothers" should be deleted once and for all (Lukasheva, 2001). In legal terms, they should be defined as a certain special object in the general system of civil rights, which can be used as a crime instrument. The "peculiarity" of such an object (individuality, independence from others) should be determined by the fact that animals must be divided into a special category or civil law group, which is located between the object and the subject of civil rights.

We believe, that such arguments are unconvincing. These are, rather, social expectations, based on the idea of a humane attitude to animals, than a legal decision. This point of view is tautological and declarative, since no specific legal boundaries are proposed for such a special object. It remains unclear how the animal must combine the provisions on common objects of civil rights and at the same time own the powers of the subject.

In our opinion, this approach is unpromising in the legal meaning. In other words, it is also inexpedient to single out the "peculiarity" of animals as a legal category, as, for example, to give a legislative definition of a person.

The provisions of the so-called property law (property right to own things), including the right of ownership (Efimova, 1998; Vlasova, 2000), apply to animals as property. Since any 
property has a feature of turnover (Art. 129 of the RF $\mathrm{CC}$ ), animals can be owned, used and disposed of, that is, they can be bought and sold, exchanged, donated, bequeathed, leased, transferred in trust management, etc.

According to its legal content, the right of ownership is uniform, the same for all, a combination of powers. Thus, the owner's rights exclude all other persons from any influence on the animal belonging to him. Such an impact is possible only at the owner's will.

Everything that the civil law regulates in relation to animals, to one degree or another, is reflected in the criminal law. Legal regulations on animals as an object of civil rights and provisions of property law stipulated a criminal law prohibition on another's property. Animals must not be abducted, removed from lawful possession, illegally turned in someone's favor or in favor of other persons.

Animals as other's property cannot be destroyed or "damaged" (cause injuries or harm), that is, brought into a state in which they lose economic value, economic affiliation, properties of functional support, etc. Accordingly, a violation of property rights to another's property may entail criminal liability for a theft, a robbery, a misappropriation, a fraud, an extortion, a destruction or a damage to property, etc.

In civil law, there is such a category of property as "no man's thing," which is directly related to animals. The unnaturalness of biological individuals is characterized primarily by their natural qualities. Not belonging to anyone representatives of the fauna are, as a rule, wild animals. Such biological objects are usually understood as those who are in a state of so-called natural freedom.

In such a state, any animal from the day of biological birth determines its own behavior as part of its genetic program. Thus, a wild animal that previously does not belong to anyone (no one's thing) can become the object of the property right of any person who legally extracts (gets, catches) it from its natural habitat.

The civil law regulations on no one's thing stipulated a criminal law ban on the inadmissibility of violation of the regulatory order of a prey, a catch and a hunting of wild animals. The criminal liability for such acts is determined by the so-called poaching crimes (Articles 256, 258, 258.1 of the Criminal Code of the Russian Federation). 
Res nullius is in no way connected with the labor and material costs of people until the day it was acquired. However, when wild animals are lawfully caught or born in captivity, that is, they are "supported" by a person, they acquire the status of another's property. The animal's owner may possess, use and dispose of them at his discretion. In cases where the owner's will is violated, namely, animals are destroyed or abducted, the guilty person can be prosecuted under the Criminal Code of the Russian Federation for crimes against property.

The Civil Code of the Russian Federation also identifies such a category of property as "ownerless things". They are those material objects that do not have an owner or its owner is unknown. The thing considered to be ownerless is also if the person refused the ownership right (part 1 of article 225 of the RF CC). In these cases, we are no longer talking about the object of civil rights, but about the object of civil legal relations, which, of course, is not the same thing.

Stray animals also belong to the category of ownerless (res nullius) things, that is, those that do not have an owner (Article 230 of the RF CC). In other words, because there is no supervision that there is no the master. Departmental regulations often use impersonal definitions of animals such as no man's things. In different periods they were called: stray animals, homeless, unproductive, as well as special raw materials, household garbage, etc.

Of course, the civil law essence of such animals from the use of negative or impersonal definitions has not changed. In any capacity, ownerless animals retain the status of other movable property. Due to their physical and biological nature, they simply cannot belong to the opposite category - to immovable things.

Thus, the property under abeyance can be: domestic animals, united by the general term "cattle" (horses, cows, camels, sheep, etc.); others, but also domestic (dogs, cats, geese, ducks, etc.); wild, held in captivity, but found at large. However, in the legal literature the view was expressed that we talk not only about domestic animals, but at least about domesticated animals in Art. 137 of the RF CC (Karpovich, 1995). But the term “domesticated" was not explained. 
In our opinion, it is a controversial point of view, since the concept of "domesticated" is collective and indefinite and can be interpreted broadly. We suppose they can be wellfed but certainly wild animals: moose, deer, bison, wild boars, and others, which are kept in hunting farms on an extended but limited space, which is neither a reservation, nor a reserve, no other conservation area.

In principle, domesticated animals are not a strict legal concept. There is no ranking depending on the purpose and social functions in the legislation on animal's world. There is no clear division of them into domesticated, breeding, agricultural, horse-drawn, decorative, sporting, captive, etc. When such animals get out of social control, they are completely can fall into the category of ownerless things (street animals). Consequently, the concepts of "ownerless," "stray" have only a social character and are artificially introduced into the system of civil law relations.

The civil legal status of animals as property (of an object, a thing) has determined an insoluble conflict between legal establishments and morality. The fact is that according to the
Second Part of Article 137 of the RF CC cruelty to animals, violation of the principle of humanity is unacceptable. The contradiction lies in the fact that any material thing in itself is "dead," that is, there is no life in it, however, such objects must be treated humanely as a living substance. Accordingly, the formal logic is violated: the living cannot be simultaneously dead.

Jurisprudence and criminal law, among other things, are forced to deal with the paradoxes of these "living dead" and introduce some conventions that delimit one from another. In relation to animals, such a generalizing (compromise) category is their definition as "animated objects," that is, living creatures with a soul (Thurow, 2018).

The central link is the word "animated," that is, the presence of a soul in material substance, in this concept. The term itself is vague, it is used in border areas: philosophy, ethics, psychiatry, social psychology, in law, and in other areas of cognition and, accordingly, is interpreted differently.

In idealistic philosophy, the "soul" was understood to mean a separate intangible substance, independent of the body, or a special force that dwells in the body of a man 
and an animal (Ilyichev \& Fedoseev, 1983). In turn, materialists have always sought to understand the soul as a property of matter and consider it as a category identical to consciousness or mind (Blauberg, 1966).

In psychology and psychiatry (which operate under the category of "mental illness"), the soul is defined as the inner world of a person, his selfconsciousness or as a combination of mental phenomena, systematic properties of the brain (Chudnovsky \& Chistyakov, 1997; Eryshev \& Sprints, 2005). In theology (religion), the soul is a certain living substance, life-giving and knowing principle (Frank, 1917). The soul is a combination of organic and sensory perceptions, traces of memories, thoughts, feelings and volitional acts, but without participation in this complex of high manifestations of the spirit. The soul is the totality of all spiritual activity, and the spirit and the soul are a single entity (Voino-Yasenetsky, 1991).

While analyzing the subject of cruelty to animals (Article 245 of the Criminal Code of the Russian Federation), another methodical approach is most often used - the identification of species of fauna. So, E. V. Bogatova (Bogatova, 2012) and
K. P. Semenov (Semenov, 2015) suppose that any mammals can be such animals; V.N. Kitaeva believes that the subject of this crime is all vertebrate animals, including reptiles, amphibians and fish (Kitaeva, 2010).

In support of her position, V. N. Kitaeva cites the following arguments: firstly, the Ukrainian legislator took this path, pointing to vertebrate animals, and secondly, judicial practice sometimes recognizes fish as the subject of a crime. But, as the author notes, she has considered 257 materials of criminal cases of cruelty to animals, and only one such case occurred. The guilty persons were held liable for the intentional destruction of 15 aquarium fish (Kitaeva, 2010).

Based on these arguments, V. N. Kitaeva proposes to specify the subject of the crime, provided for by Art. 245 of the Criminal Code. In the disposition of the norm, it is necessary, in her opinion, to single out the vertebral, that is, practically all possible of this type of zoological classification.

We suppose, it is hardly the right solution to the issue. The counterargument is based on two circumstances of a subjective and objective nature. First, considerations 
about the psychological nature of immoral acts against animals; secondly, the inconsistency of this proposal with the existing zoological system.

Cruelty to animals is a crime against public morality, and accordingly, such actions always affect the foundations of the mental well-being of many people. Cruelty towards representatives of the animal kingdom causes public indignation or negative emotional reactions, as it offends the deepest feelings of people, hurts them psychologically. The physical torment of the neighbors on the planet is perceived as the result of unconditional evil and causes pity and compassion for the victims. This subjective perception is based on the objective factors. Moral feelings are negatively impacted because people primarily see animal suffering (Bekoff, 2007). A clear demonstration of their horror, screams (sounds) of pain, reflex movements, convulsions, painful reactions multiply the rejection of such a spectacle. Apparently, at the genetic level, many people perceive such pain as their own.

However, we cannot see physical suffering in all animals. So, for many representatives from the squamous order (the reptile class), for example, the
426 armored gecko or the newt or scolopendra from the amphibian order (amphibian class), the pain, that they experience, is invisible. At least, a person can only guess about the torment of such animals, suggest or admit the possibility that they feel. In turn, insecure considerations, mental, abstract assumptions and other "conjectures," of course, reduce the potential for a moral assessment of such an event. In other words, with the same success, a person can hypothetically imagine the physical suffering of arachnids (spiders), crustaceans, insects and fish. It is clear that people do not experience any moral experiences about this.

The second counterargument against the proposal to isolate the subject of a crime in the form of vertebrates in the law is that such a decision violates the logic of zoological classification. The fact is that all vertebrates are of the same type - chordates. There are two subtypes: the lower ones, in which the supporting axis (chord) runs along the back, and the higher ones, which have a spine, is actually the same chord. In our case, we are talking about the higher vertebrates. Five classes are distinguished in the subtype of these animals: animals (mammals), birds, 
reptiles, amphibians, and fish. Accordingly, it is not logical to include an indication of all five classes of animals in the law, since, firstly, it becomes an indefinitely voluminous legal concept, and secondly, to three classes from this list, a person does not have a moral attitude towards their physical suffering.

\section{Conclusion}

Of course, the question of the subject of the crime under Art. 245 of the Criminal Code, is very controversial. Nevertheless, it requires a legal solution, at least partially based on biological systematics. Apparently, talking about the soul of a unicellular organism or a lower, primitive multicellular one is not necessary. These animals have only sensory organs. According to V.F. Voino-Yasenetsky, they represent only "the breath of life" (Voino-Yasenetsky, 1991). In our opinion, it is advisable to supplement the criminal law norm with an indication that animal cruelty concerns only mammals and birds.

Such concretization remains arbitrary, but to a certain extent it is based on the people's traditional notions of "moral" closeness with such animals. Mammals and birds are the closest relatives of humans in their rational activity, emotions and organization of life. A similar clarification of the law is also acceptable from the point of view of legal technology.

Thus, despite the wide range of definitions of animals in the Criminal Code of the Russian Federation, the main ("remaining") part of them cannot be assigned to the subject of zoological crimes. It is due to the fact that, firstly, the criminal law is cannot protect all living creatures that live on the planet, since they are not included in the system of social relations; secondly, to harm the vast majority of fauna representatives is very difficult or even impossible with the help of other animals.

\section{References:}

Beirne, P. (2014). Theriocide: Naming animal killing. International Journal for Crime, Justice and Social Democracy, 3(2), 49-66.

Bekoff, M. (2007). The emotional lives of animals: a leading scientist explores animal joy, sorrow, and empathy-and why they matter. Novato: New World Library. 
Blauberg, I.V. (1966). Brief Dictionary of Philosophy. USSR: Izdatelstvo Politicheskoy Literatury.

Bogatova, E.V. (2012). Prevention of animal cruelty. Yekaterinburg.

Brewster, M.P., Reyes, C. (2012). Animal cruelty: a multidisciplinary approach to understanding. Durham, North Carolina: Carolina Academic Press.

Chudnovsky, V.S., Chistyakov, N.F. (1997). The basics of psychiatry.

Rostov-on-Don: Fenix.

Coorey, L., Coorey-Ewings, C. (2018). Animal Victims of Domestic and Family Violence: Raising Youth Awareness. Animal Studies Journal, 7(1), 1-40.

Efimova, L.G. (1998). About correlation of property obligations and right of obligation. State and law, 10.

Eryshev, O.F., Sprint, A.M. (2005). Psychiatry for everyone. St. Petersburg: SpetsLit.

Fischer, B. (2019). Moral Bioenhancement Probably Won't Improve Things for Animals (and May Make Them Worse). Topoi 38, 141-151. Flynn, C.P. (2011). Examining the links between animal abuse and human violence. Crime Law Social Change 55, 453-468.
428

Frank, S. L. (1917). The soul of a man. Moscow: AST.

Ilyichev, L.F., Fedoseev, P.N. (1983) Philosophical Encyclopedic Dictionary. Moscow: Sovetskaya Entsiklopediya. Karpovich, V.D. (1995). Commentary on the first part of the Civil Code of the Russian Federation for entrepreneurs. Moscow: Spark.

Kitaeva, V.N. (2010). Animals and crimes: criminal law and forensic research. Irkutsk: BSUEP.

Lukasheva, A.V. (2001). Features of the legal status of animals. Citizen and Law, 4.

Ozhegov, S.I., \& Shvedova, N. Yu. (1995). Explanatory dictionary of the Russian language. Moscow: Az.

Semenov, K.P. (2015). Animals as an object and means of crime: dis. ... cand. legal sciences. Saint-Petersburg.

Thurow, J.C. (2018). Animals with Soul. SOPHIA 57, 85-101.

Vlasova, A.V. (2000). To the discussion of property and liability rights. Jurisprudence, 2.

Voino-Yasenetsky, V.F. (1991). About the spirit, soul and body. Rostov-onDon: Obraz 